\title{
Involvement of miR-106b in tumorigenic actions of both prolactin and estradiol
}

\author{
Kuan-Hui Ethan Chen ${ }^{1}$, Karissa Bustamante ${ }^{1}$, Vi Nguyen ${ }^{1}$, Ameae M. Walker ${ }^{1}$ \\ ${ }^{1}$ Division of Biomedical Sciences, University of California, Riverside, CA 92521, USA \\ Correspondence to: Ameae M. Walker, email: ameae.walker@ucr.edu
}

Keywords: miR-106b, prolactin, estradiol, p21, breast and prostate cancer

Received: February 04, $2017 \quad$ Accepted: March 21, $2017 \quad$ Published: March 31, 2017

Copyright: Chen et al. This is an open-access article distributed under the terms of the Creative Commons Attribution License (CC-BY), which permits unrestricted use, distribution, and reproduction in any medium, provided the original author and source are credited.

\section{ABSTRACT}

Prolactin promotes a variety of cancers by an array of different mechanisms. Here, we have investigated prolactin's inhibitory effect on expression of the cell cycle-regulating protein, p21. Using a miRNA array, we identified a number of miRNAs upregulated by prolactin treatment, but one in particular that was strongly induced by prolactin and predicted to bind to the 3'UTR of p21 mRNA, miR-106b. By creating a p21 mRNA 3'UTR-luciferase mRNA construct, we demonstrated degradation of the construct in response to prolactin in human breast, prostate and ovarian cancer cell lines. Increased expression of $\mathbf{m i R - 1 0 6 b}$ replicated, and anti-miR-106b counteracted, the effects of prolactin on degradation of the 3'UTR construct, p21 mRNA levels, and cell proliferation in breast (T47D) and prostate (PC3) cancer cells. Increased expression of miR-106b also stimulated migration of the very epithelioid T47D cell line. By contrast, anti-miR-106b dramatically decreased expression of the mesenchymal markers, SNAIL-2, TWIST-2, VIMENTIN, and FIBRONECTIN. Using signaling pathway inhibitors and the 3'UTR construct, induction of miR-106b by prolactin was determined to be mediated through the MAPK/ERK and PI3K/Akt pathways and not through Jak2/ Stat5 in both T47D and PC3 cells. Prolactin activation of MAPK/ERK and PI3K/Akt also activates ERa in the absence of an ERa ligand. $17 \beta$-estradiol promoted degradation of the construct in both cell lines and pre-incubation in the estrogen antagonist, Fulvestrant, blocked the ability of both prolactin and $17 \beta$-estradiol to induce the construct-degrading activity. Together, these data support a convergence of the prolactin and $17 \beta$-estradiol miR-106b-elevating signaling pathways at ERa.

\section{INTRODUCTION}

Prolactin is a peptide hormone produced and released from many tissues, but in largest quantity from the pituitary gland [1]. The best known functions of prolactin are in the mammary gland where prolactin promotes gland development during pregnancy, the synthesis of milk, and maintenance of milk secretion [2]. However, prolactin also functions in immune regulation [3-5], adipocyte differentiation [6, 7], islet proliferation $[8,9]$ and regulation of bone density $[10,11]$. In addition, more and more evidence has accumulated indicating that prolactin promotes tumorigenesis in various types of cancers, including breast [12-14], prostate [14,15], ovary $[14,16]$, liver [17], and brain [18], as well as stimulating the growth of pituitary tumors $[19,20]$. One of the tumor- promoting mechanisms is decreased expression of the cell cycle inhibitor CDKN1A, also known as p21 [14]. A reduction in $\mathrm{p} 21$ expression may have a direct effect on cell proliferation, but may also contribute to anti-estrogen and other drug resistance in some cancers [21-26]. As might be expected, the expression of $\mathrm{p} 21$ is tightly regulated by several molecules, including p53 [27], BRCA1 [14, 28], TGF- $\beta$ [29], RAR/RXR [30] and the vitamin D receptor [31]. In addition to expression of $\mathrm{p} 21$, cellular localization of p21 is also related to the therapeutic resistance [32]. Restriction of p21 to the cytosol is regulated through post-translational modification on threonine 145, which is phosphorylated by Akt, PKA or pim-1 kinase [32-34]. Therefore, regulation of $\mathrm{p} 21$ expression and localization is of importance in both cancer development and therapeutic resistance. 
Estrogens also contribute to progression of a number of cancers [35-38]. We and others have identified a synergy between prolactin and estrogen in the promotion of breast cancer [39-42], and the ability of prolactin to activate the estrogen receptor $\alpha(\mathrm{ER} \alpha)$ in the absence of an ER $\alpha$ ligand [40, 41]. Thus, studying the interplay between these two hormones in cancer progression is important.

We have previously demonstrated that prolactin regulates p21 transcription through inhibition of BRCA1 function [14]. In the current study, we have determined the existence of an additional mechanism through which prolactin decreases the amount of $\mathrm{p} 21$, the induction of miR-106b, a mechanism duplicated by estradiol. Further, that increased expression of miR-106b causes increased cell number and enhanced migratory capacity.

\section{RESULTS}

\section{Prolactin effects on miRNA expression}

To explore how prolactin might reduce expression of p21 mRNA, we performed a miRNA microarray in T-47D breast cancer cells. To help refine our analysis, we used both prolactin, which reduces, and the selective prolactin receptor modulator, S179DPRL, which elevates, p21 $[14,43]$. Prolactin and S179DPRL bind to the same receptors [44], and have some functions in common [45], but in regard to cell proliferation, prolactin stimulates [46], while S179DPRL inhibits $(14,43,45,46)$. Using a 2-fold change in expression as our stringency cutoff, there were 21 miRNAs upregulated by prolactin (Table 1). Among these miRNAs, miR-106b has been shown to target to the 3' UTR of p21 mRNA directly [47]. None of the other 20 miRNAs upregulated by prolactin is predicted to interact directly with any region of p21 mRNA using online database miRDB analysis [48, 49]. Most these other miRNAs have been reported to be associated with reduced expression of p21 indirectly [50-52]. miR-107, miR-153 and miR-142-3p indirectly reduce $\mathrm{p} 21$ expression through targeting the upstream regulators, FOXO1, PTEN and FOXO4, respectively [50-52]. We therefore focused further analysis on miR-106b. Consistent with a p21elevating effect of S179DPRL [46], S179DPRL also decreased expression of miR $106 \mathrm{~b}$ by $43 \%$ compared to the PBS control (Figure $1 \mathrm{~A}$ ).

To substantiate a role for miRNA in the degradation of p21 mRNA in the current study, we created a plasmid construct by conjugating the 3'UTR of p21 mRNA downstream of a luciferase reporter. If there were miRNAs targeted to the 3'UTR, this would lead to degradation of luciferase mRNA and therefore would reduce translated luciferase activity (Figure 1B). Consistent with the microarray experiment, when T-47D cells were transfected with this plasmid and treated with prolactin or vehicle for 72 hours, treatment with prolactin significantly reduced the luciferase activity (Figure 1C). In addition to T-47D cells, this effect was also reproduced in human prostate cancer PC3 cells (Figure 1D). To further illustrate this was not limited to the 2 cell types we focused on for most of the study, we also examined a second human breast cancer cell line, MCF-7, and 3 human ovarian cancer cell lines. For these additional cell lines the effect of prolactin on luciferase activity is shown at 24 hours in Figure 1E-1H. Prolactin caused a significant reduction in luciferase activity in MCF-7, TOV-112D, and OV 90 cells in this time frame, indicating prolactin induction of miRNA targeted to the 3'UTR of p21 mRNA. The degree of response was very cell line dependent, ranging from a $15 \%$ reduction of luciferase activity in MCF7 cells to an $80 \%$ reduction in TOV- $112 \mathrm{D}$ cells.

To demonstrate that the effect of prolactin was mediated through miR-106b, we constructed shRNA plasmids to be used to increase expression of either miR-106b or anti-miR-106b. Increased expression of miR$106 \mathrm{~b}$ essentially eliminated p21 mRNA in T47D cells, whereas anti-miR-106b increased p21 mRNA. In PC3 cells, which grow more rapidly and are less epithelioid, increased expression of miR106b had no effect, while increased expression of anti-miR106b quadrupled the expression of p21 mRNA (Figure 2A and 2B). Using the luciferase assay to assess the effect of increased expression with and without prolactin, increased expression of miR-106b reduced luciferase activity and prolactin treatment did not augment this effect. However, the luciferase-lowering effect of prolactin was blocked when there was increased expression of anti-miR-106b (Figure 2C and 2D). Collectively, these results show that prolactin induced the production of miR-106b and that this then targeted the $3^{\prime}$ UTR of p21 mRNA.

\section{Cells expressing more miR-106b were more aggressive}

To determine the outcome of upregulation of miR-106b in cancer, we first examined effects on relative cell number, as assessed by MTS assay, with increased expression of miR-106b or anti-miR106b in the absence or presence of prolactin. As seen in Figure 3A, increased expression of miR-106b or anti-miR106b in T47D cells did not cause any effect on cell number in the absence of prolactin. Prolactin alone (with control shRNA) increased the relative number of cells by $35 \%$ during the 72-hour incubation. Additional expression of miR-106b in the presence of prolactin doubled the response. By contrast, increased expression of anti-miR-106b in the presence of prolactin decreased cell number below that without prolactin. In the PC3 cell line, which grows rapidly, increased expression of miR-106b or incubation with prolactin did not significantly increase cell number. However, increased expression of anti-miR-106b significantly inhibited growth of cells in the presence of prolactin (Figure 3B). These results suggest that increased 
Table 1: Upregulated miRNAs ( $>2$ fold) by prolactin

\begin{tabular}{|c|c|}
\hline miRNA & Fold \\
\hline miR-10b-5p & 2.648065866 \\
\hline miR-95-3p & 2.365516801 \\
\hline miR-92-3p & 2.278490033 \\
\hline miR-92b-3p & 2.26453033 \\
\hline miR-27a-3p & 2.250477655 \\
\hline miR-26b-5p & 2.225025659 \\
\hline $\operatorname{miR}-17-3 p$ & 2.210714719 \\
\hline miR-215-5p & 2.196169084 \\
\hline miR-101-1-3p & 2.173145188 \\
\hline miR-30a-3p & 2.164483133 \\
\hline miR-142-5p & 2.154083454 \\
\hline miR-214-3p & 2.127021904 \\
\hline miR-132-3p & 2.100969166 \\
\hline miR-142-3p & 2.097205532 \\
\hline miR-185-5p & 2.090877882 \\
\hline miR-153-3p & 2.047451196 \\
\hline miR-372-3p & 2.029475511 \\
\hline miR-186-5p & 2.011486344 \\
\hline miR-103-3p & 2.006442321 \\
\hline miR-107 & 2.000847941 \\
\hline miR-106b-5p & 2.000066166 \\
\hline
\end{tabular}

levels of miR-106b alone are insufficient to cause an increase in cell number, but that by reducing p21 levels, any promotion of proliferation can be enhanced. By contrast, increased levels of anti-miR-106b effectively block proliferation.

We next examined whether increased expression of miR-106b affected cell migration. T-47D cells were chosen for this analysis because they are very epithelioid in nature and migration rates are normally very slow. Cells were seeded in a constrained area in the center of the well and then transfected with control shRNA or miR-106b shRNA plasmid. As seen in Figure 3C, most control shRNAtransfected cells remained in the original area. However, cells with increased expression of miR-106b dispersed to a greater radius. Incubation in prolactin (with control shRNA), had a similar effect to transfection with miR-106b shRNA (compare Figure 3C and 3D). However, combining increased expression of miR-106b with incubation in prolactin did not further increase the amount of migration. As would be predicted from these results, expression of anti-miR-106b decreased migration to about the level seen in the absence of prolactin and additional miR-106b, thereby confirming a role for miR-106b in the promotion of migration.

To further confirm an effect on migratory capacity, we examined the expression of genes characteristic of an epithelial to mesenchymal transition. Increased expression of miR-106b with prolactin treatment in T47D cells increased expression of fibronectin and vimentin, whereas increased expression of anti-miR-106b along with prolactin treatment decreased the expression of fibronectin, vimentin, twist 2 and snail2, with the last reduced to undetectable levels, leaving us no ability to determine significance levels (Figure 3E-3H). Taken together, these results suggest a high impact of miR-106b on proliferative and metastatic aspects of tumor progression.

\section{The induction of miRNAs by prolactin was mediated through MAPK, PI3K and activation of the estrogen receptor}

To identify which prolactin signaling pathway/s contributed to the induction of the miRNA(s), PC3 and T-47D cells were pre-treated with different signaling inhibitors (PD98059 for MAPK/ERK, Wortmannin for PI3K/Akt, AG490 for Jak2/Stat5) and transfected with the luciferase-p21 3' UTR plasmid. The effect of these inhibitors was also validated by examining activation of the appropriate signaling molecules using Western blot (data not shown). Because these inhibitors negatively impact cell viability when used for extended periods, effects on luciferase activity were measured 24 hours 
after transfection and incubation with the inhibitors, with 20 of those hours in the absence or presence of prolactin. This protocol was sufficient for all inhibitors except wortmannin, which still had a small effect $(\sim 20 \%$ in both the absence and presence of prolactin) on cell viability in the 24 hour time frame (data not shown). To compensate, data are expressed as a percent of luciferase activity in the absence of prolactin. i.e. the graph is specifically showing the effect of the inhibitors on the induction of p21-targeting miRNA as a function of prolactin treatment. Given that we are looking at increases in luciferase activity if the signaling pathway is blocked, an increase in translated and active luciferase is unlikely to be the result of a decrease in cell viability. While one tends to think of the Jak2/ Stat5 pathway as being of primary importance to prolactin signaling, AG490 had no effect on the induction of miRNA by prolactin. However, prolactin failed to reduce luciferase activity when PD98059 or wortmannin was present in the medium (Figure 4A in T47D cells and 4B in PC3 cells). Thus, prolactin signals through MAPK/ERK and PI3K/Akt to elevate miRNA targeting the p21 mRNA 3'UTR. Wortmannin is a more potent PI3K/Akt inhibitor than the commonly used LY294002. However, at higher concentrations, wortmannin may also inhibit other PI3 related kinases such as mTOR, DNA-PK, and ATM [53]. As the concentration we used may also block these other kinases, we therefore cannot exclude the possibility that these other kinases might also be involved in the miRNA production.

Prolactin signaling through MAPK/ERK and PI3K/ Akt pathways also activates ER $\alpha$ in the absence of an $\mathrm{ER} \alpha$ ligand [40]. We therefore examined the potential role for activated ER $\alpha$ in the production of miR-106b. Cells were pre-treated with the ER $\alpha$ inhibitor, ICI-182780, and then transfected with the luciferase-p21 3'UTR plasmid. As seen in Figure 4C and 4D, addition of ICI-182780 not only blocked the luciferase degradation promoted by prolactin, but also increased the amount of luciferase activity compared to control. In other words, blockade/ degradation of ER $\alpha$ inhibited the ability of prolactin to elevate the miRNA in both breast cancer and prostate cancer cell lines.

To further demonstrate that activation of ER $\alpha$ can result in the production of miRNA targeting the p21
A

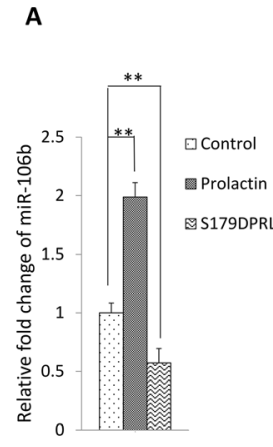

E

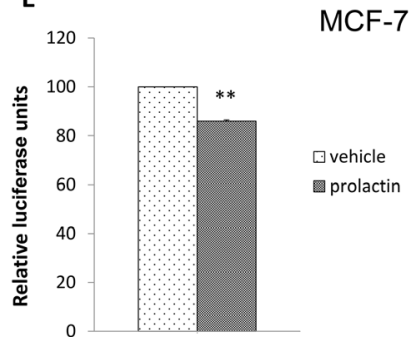

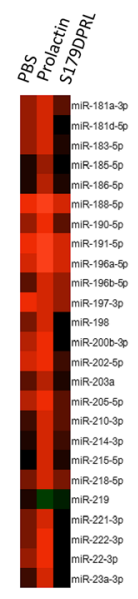

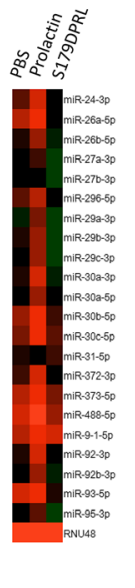

$\mathbf{F}$

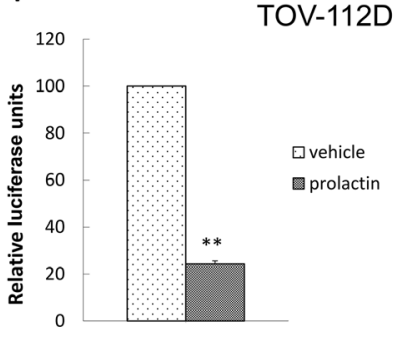

B

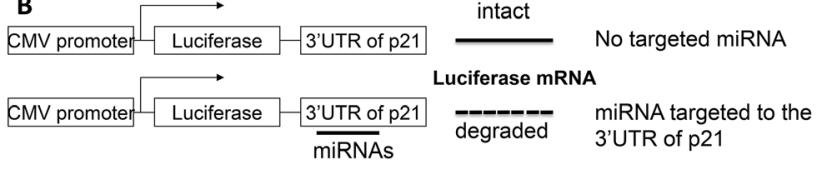

C

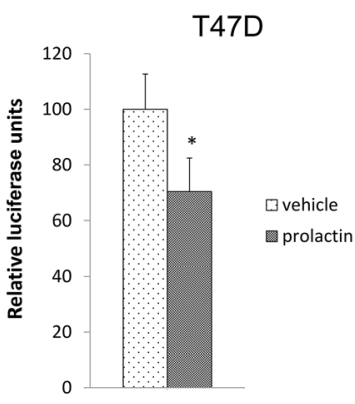

G
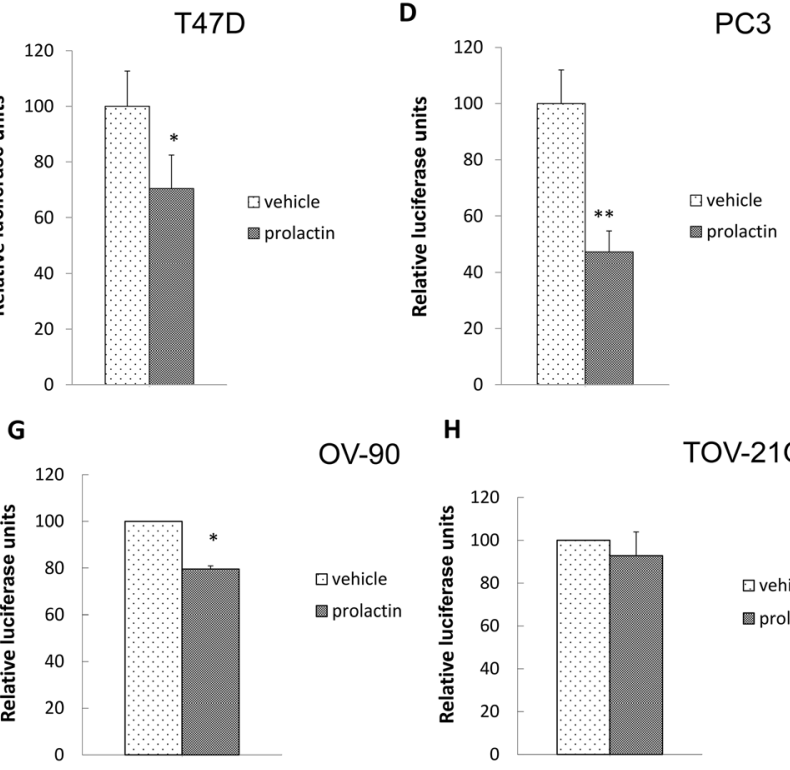

$\mathrm{H}$

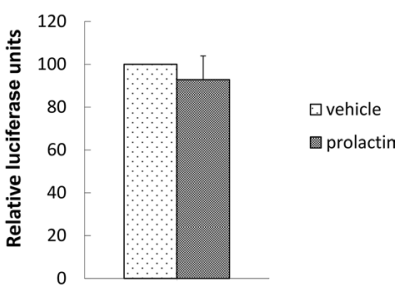

Figure 1: Prolactin treatment induced miR-106b targeted to the $3^{\prime} \mathrm{UTR}$ of the p21 in cancers. (A) T47D cells were treated with vehicle control, $100 \mathrm{ng} / \mathrm{mL}$ prolactin or $100 \mathrm{ng} / \mathrm{mL}$ selective prolactin receptor modulator, S179DPRL, for 72 hours. Total RNA was extracted and $5 \mu \mathrm{g}$ total RNA from each treatment was subjected to miRNA array. (B) Illustration of luciferase-3'UTR assay to detect miRNA production. When there was miRNA production that bound to the 3'UTR region, this would lead to degradation of luciferase mRNA and reduced luciferase signals. The breast cancer cell line, T47D $(\mathbf{C})$ and prostate cancer cell line, PC3 cells (D) were transfected with luciferase-p21 mRNA 3'UTR plasmid followed by $100 \mathrm{ng} / \mathrm{mL}$ prolactin treatment for 72 hours. This analysis was also performed in one additional breast cancer cell line, MCF7 (E) and 3 ovarian cancer cell lines, TOV-112D (F), OV-90 (G) and TOV-21G (H) with prolactin treatment limited to a 24 hour period in these cases. Luciferase activity was then measured. Each luciferase activity value from vehicle-treated cells was set as 100. Data are presented as the mean \pm S.D.; $* P<0.05$ and $* * P<0.01$ (compared with vehicle treatment). 
mRNA 3'UTR, cells were transfected with the luciferase construct and treated with $17 \beta$-estradiol. As seen in Figure $5 \mathrm{~A}$ and $5 \mathrm{~B}$, estradiol induces miRNAs targeting the 3'UTR of p21 mRNA in both breast cancer and prostate cancer cell lines. In addition, when cells were pretreated with ICI-182780, the reduction of luciferase activity by estradiol was relieved (Figure 5C and 5D).

Taken together, these data indicate that activated $\mathrm{ER} \alpha$ mediates the effect of both prolactin and estradiol on the production of miRNA targeting the $3^{\prime} \mathrm{UTR}$ of the p21 mRNA.

\section{DISCUSSION}

There are many publications supporting roles for prolactin in the progression of a variety of cancers $[13,16,54-56]$. These include various pro-proliferative, anti-apoptotic and pro-metastatic roles. In addition, prolactin may contribute to therapeutic drug resistance $[57,58]$. The development of resistance to therapy can occur by a variety of mechanisms, but loss of p21 expression is a common factor [21, 23-26]. Identification of mechanisms governing p21 expression may lead to
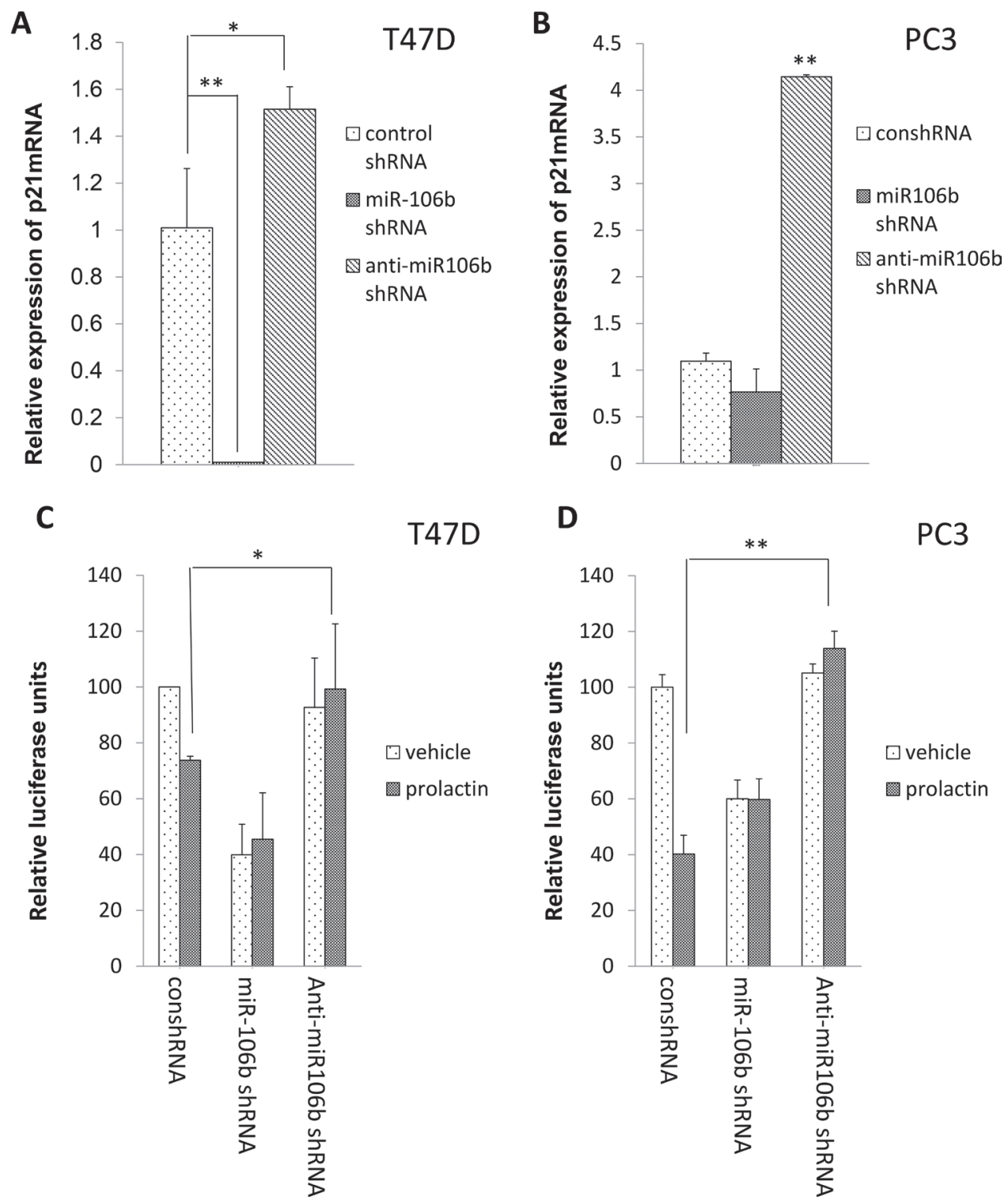

T47D

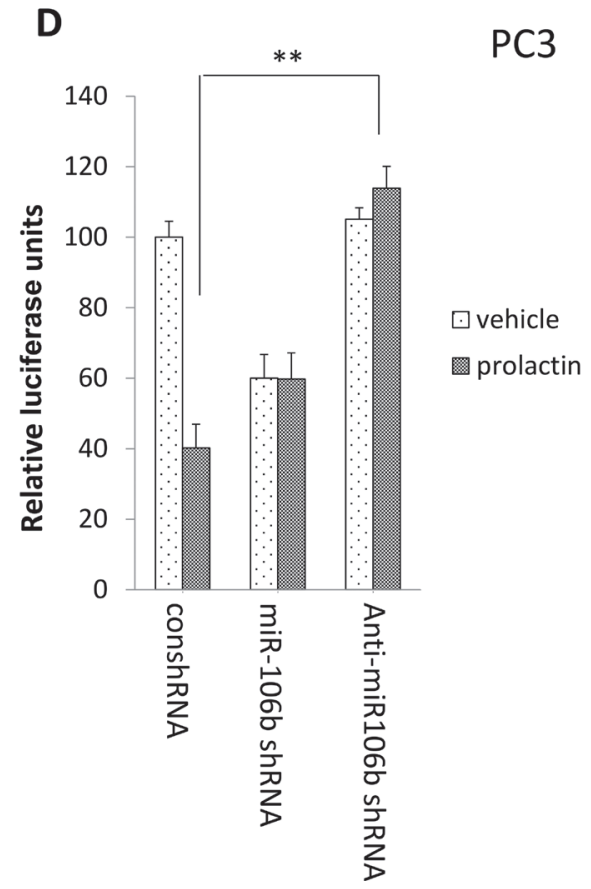

Figure 2: Inhibition of miR-106b by anti-miR106b shRNA blocked prolactin mediated effect on both the 3'UTR of p21 mRNA and p21 mRNA expression. Increased expression of miR-106b shRNA reduced p21 mRNA in T47D cells (A) while increased expression of anti-miR-106b shRNA resulted in more p21 mRNA in PC3 cells (B). The expression of p21 transcript was normalized to GAPDH. Each transcript level from non-treated cells was set as 1. Both T47D (C) and PC3 (D) cells were co-transfected with luciferase-p21 3'UTR plasmid and control shRNA/ miR-106b shRNA/ anti-miR-106b shRNA and treated with $100 \mathrm{ng} / \mathrm{mL}$ prolactin or vehicle for 72 hours. Luciferase activity was then measured. Each luciferase activity value from vehicle treated cells was set as 100 . Data are presented as mean \pm S.D.; $* P<0.05$ and $* * P<0.01$ (compared with vehicle treatment). 
development of new therapeutics, as well as to strategies to prevent development of resistance to current therapies.

To explore how prolactin might reduce expression of p21 mRNA, we performed a miRNA microarray in T-47D breast cancer cells. Using a 2-fold change as the stringency cutoff, 21 miRNAs were upregulated by prolactin. To help sort through which of these to focus on, we used two approaches. The first approach was to compare with the effect of S179DPRL. While prolactin decreases expression of p21, S179DPRL increases p21 $[14,43]$. Although the mechanism for increasing $\mathrm{p} 21$ might not have been through decreased production of miRNAs, we could at least expect to be able to eliminate some miRNAs from further consideration if they were also increased by S179DPRL. miR-9-1-5p is a good example of one eliminated. The second approach was to examine these 21 miRNAs for predicted direct interactions with any region of $\mathrm{p} 21 \mathrm{mRNA}$ by online database miRDB search $[48,49]$. miR-106b was the only predicted miRNA and had been shown to interact with p21 mRNA directly [47], although its role as a mediator of any of prolactin's functions had not been described. For the remaining 20 miRNAs, literature suggested an indirect regulation on p21 expression. For example, miR-107, miR-153, and miR-142-3p had been shown to reduce p21 expression through targeting the upstream regulators, FOXO1, PTEN
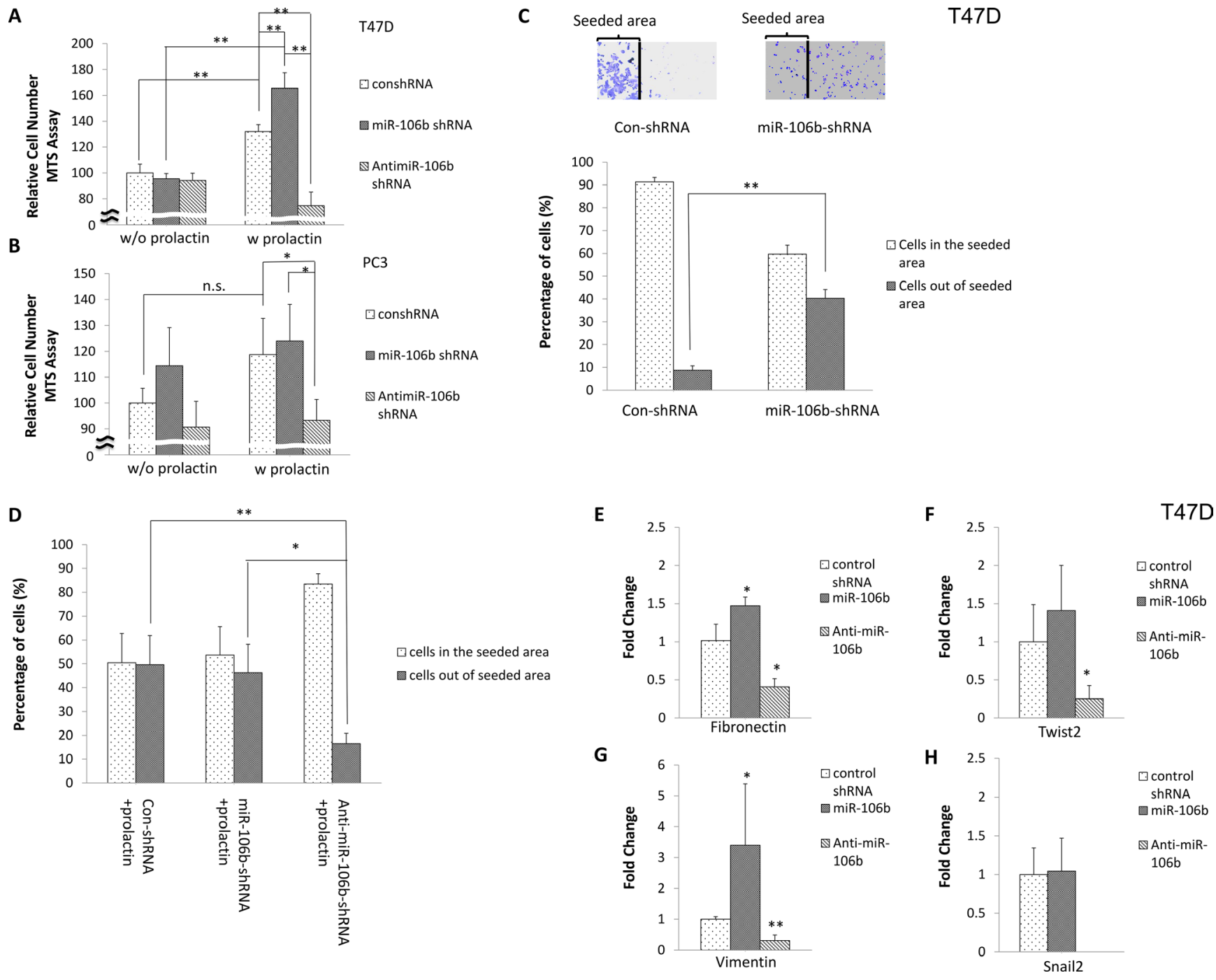

Figure 3: Effect of miR-106b on cell number, cell migration and mesenchymal gene expression. 10,000 T47D (A) and PC3 (B) cells were transfected with control shRNA, miR-106b shRNA or anti-miR-106b shRNA plasmid and treated with vehicle (left panel) or $100 \mathrm{ng} / \mathrm{mL}$ prolactin (right panel) for 72 hours. Relative cell number was then measured by MTS assay. Data are presented as the mean \pm S.D.; ${ }^{*} P<0.05$. T47D cells were seeded in the constrained area and transfected with control shRNA or miR-106b shRNA plasmid in the absence (C) or presence (D) of prolactin. After 72 hours, the distribution of cells was counted in both the original seeded area and outside this area. $(\mathbf{E}-\mathbf{H})$. T47D cells were transfected with control shRNA, miR-106b shRNA or anti-miR-106b shRNA plasmid in the presence of $100 \mathrm{ng} / \mathrm{mL}$ prolactin for 72 hours. The expression of mesenchymal genes was analyzed by real time PCR. The expression of transcript was normalized to GAPDH. Each transcript level from control shRNA transfected cells was set as 1 . Data are presented as mean \pm S.D.; $* P<0.05$ and ${ }^{*} * P<0.01$ (compared with control shRNA transfection). 
and FOXO4, respectively [50-52]. Our focus was then on miR-106b. miR-106b was not only increased by prolactin, but decreased by S179DPRL, suggesting in fact that at least part of the mechanism used by S179DPRL to elevate $\mathrm{p} 21$ is a reduction in $\mathrm{miR}-106 \mathrm{~b}$.

Using the artificial construct, the data presented show that prolactin stimulates the production of a miRNA that targets the $3^{\prime}$ UTR of p21 mRNA and that this is duplicated by increased expression of miR-106b and antagonized by anti-miR-106b. Furthermore, that the effects of miR-106b and anti-miR106b in the luciferase assay are translated to effects on levels of p21 mRNA. In T47D cells, increased expression of miR-106b essentially eliminated p21 mRNA, while anti-miR-106b had little

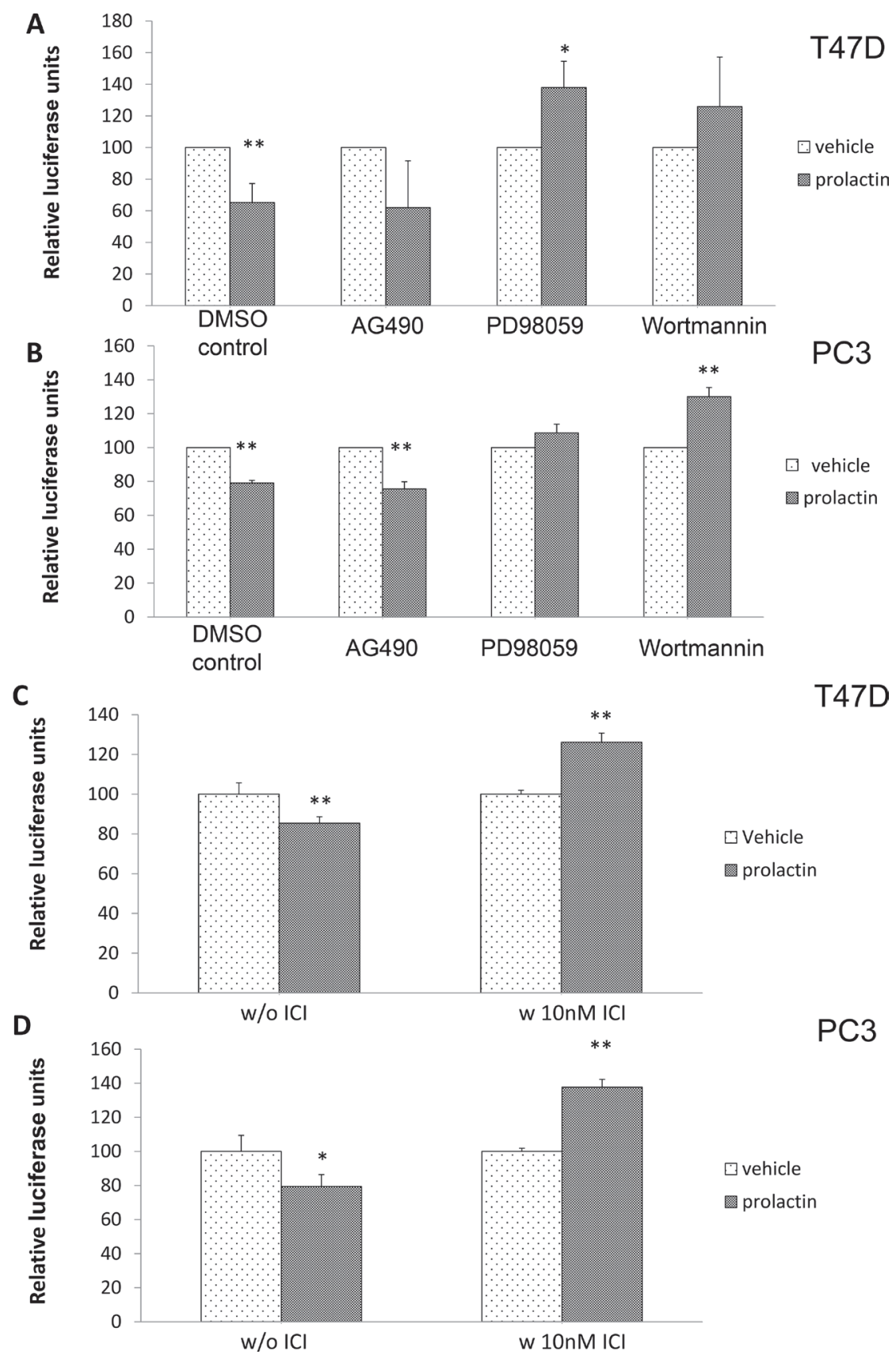

Figure 4: Prolactin activation of MAPK/ERK, PI3/Akt and ER $\alpha$ are involved in miRNA induction targeted to the 3'UTR of p21 mRNA. T47D (A) and PC3 cells (B) were transfected with the luciferase-p21 3'UTR plasmid and pre-treated with DMSO (control), $10 \mu \mathrm{M}$ AG490, $20 \mu \mathrm{M}$ PD98059 or $1 \mu \mathrm{M}$ Wortmannin for 4 hours prior to the addition of $100 \mathrm{ng} / \mathrm{mL} \mathrm{prolactin}$ or vehicle for 20 hours. Luciferase activity was then measured. Both T47D (C) and PC3 (D) cells were transfected with the luciferase-p21 3'UTR plasmid and treated with DMSO control (left panel) or $10 \mathrm{nM} \mathrm{ICI}-182780$ (right panel) in the presence of $100 \mathrm{ng} / \mathrm{mL}$ prolactin for $20 \mathrm{hours}$. Luciferase activity was then measured. Each luciferase activity value from vehicle-treated cells was set as 100 . Data are presented as mean \pm S.D.; $* P<0.05$ and $* * P<0.01$ (compared with vehicle treatment). 
effect. By contrast, miR-106b had little effect on p21 mRNA in PC3 cells, while anti-miR-106b quadrupled the amount of p21 mRNA. These results are consistent with different baseline levels of p21 in the two cell lines, with levels of p21 higher in the slower growing and more epithelioid T47D cell line. However, the amount of p21 mRNA did not translate to a change in cell number unless prolactin was also present. Thus, prolactin has additional functions that affect cell number beyond those mediated by miR-106b. To this point, in a previous publication [14] we demonstrated that prolactin regulates transcription of the $\mathrm{p} 21$ gene by interfering with BRCA1 transactivation.
Therefore, in response to prolactin, one might expect a greater reduction in $\mathrm{p} 21$ and a greater effect on cell number than that brought about only by increased expression of miR-106b. Alternatively, a greater effect of prolactin on cell number versus that produced by increased expression of miR-106b might be expected as a result of prolactin's ability to stimulate the cell cycle $[59,60]$. Given the ability of increased miR-106b to reduce p21 mRNA to essentially zero (albeit mRNA and not protein) and that this does not cause an increase in cell number, the most likely of these two explanations is that the additional effect of prolactin is pro-proliferative rather than anti-apoptotic.

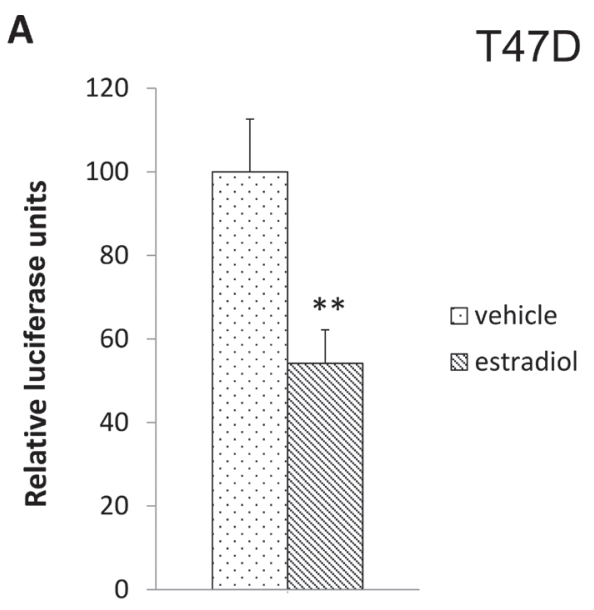

B

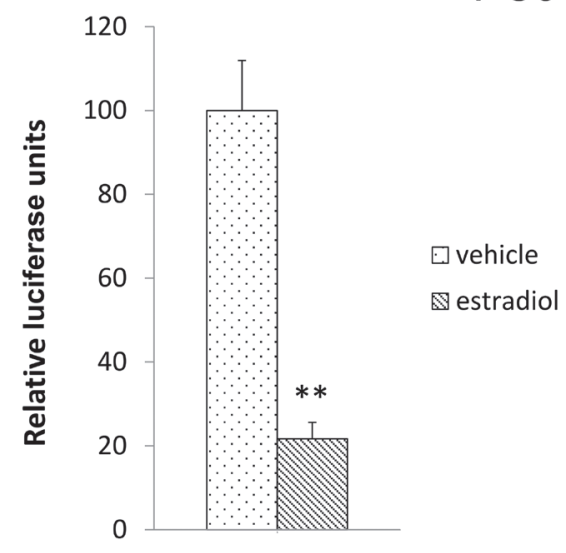

C

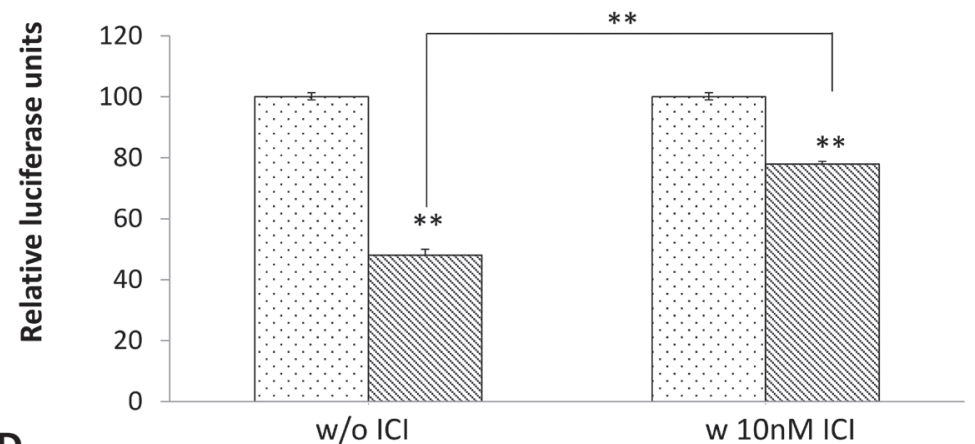

T47D

D

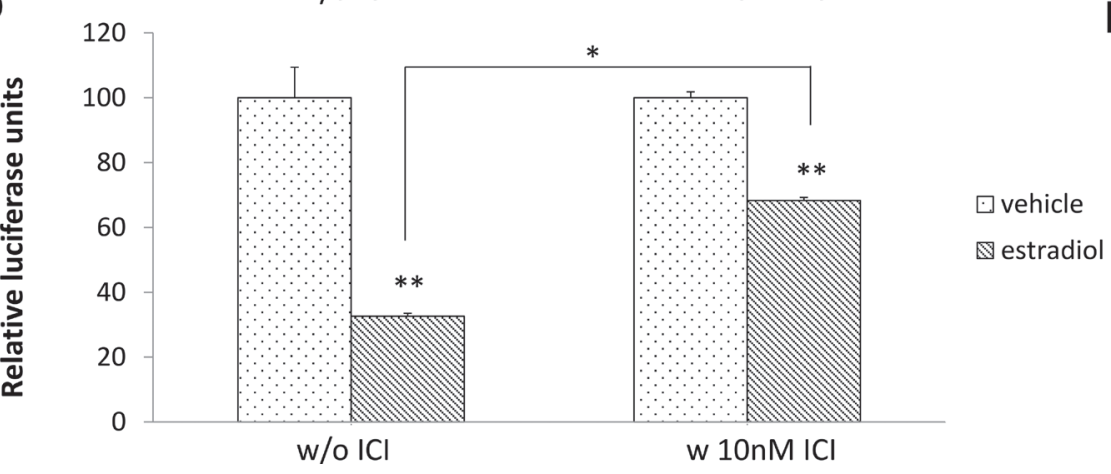

Figure 5: Activation of ER $\alpha$ by 17ß-estradiol significantly induced miRNA production that bound to the 3'UTR of the p21 mRNA construct. T47D (A) and PC3 cells (B) were transfected with the luciferase-p21 3'UTR plasmid followed by $1 \mathrm{nM}$ 17ß-estradiol treatment. Luciferase activity was then measured after 72 hours. Both T47D (C) and PC3 (D) cells were transfected with the luciferase-p21 3'UTR plasmid and treated with DMSO control (left panel) or $10 \mathrm{nM}$ ICI-182780 (right panel) in the presence of $1 \mathrm{nM}$ $17 \beta$-estradiol for 20 hours. Luciferase activity was then measured. Each luciferase activity value from vehicle-treated cells was set as 100 . Data are presented as mean \pm S.D.; $* P<0.05$ and $* * P<0.01$ (compared with vehicle treatment). 
In addition to oncogenic miR-106b, prolactin also upregulated other oncomirs such as members of the miR-17/92 family. Interestingly, the only 2 miRNAs downregulated by prolactin, miR-219 and miR-31, exhibit antitumor effects [61-63]. These data are supportive of multiple tumorigenic roles for prolactin.

In addition to miR-106b, miR-106a was also induced by prolactin (1.5 fold), but to a level below the stringency of our microarray analysis. This miRNA is known to directly target the 3'UTR of p21. Therefore, the effect of prolactin to decrease p21 mRNA could be regulated by both $\mathrm{miR}-106 \mathrm{~b}$ and miR-106a, but, based on relative expression levels, the contribution from miR-106a is less.

The data also demonstrate that increased expression of miR-106b contributes to cell migration, which is consistent with previous studies by others. For example, Gong et al. [64] and Yau et al. [65] showed increased metastasis and migration in breast and hepatocellular carcinoma cells, respectively, with increased expression of miR-106b. Furthermore, induction of miR-106b is found in multiple types of cancers, including breast, prostate and ovarian cancers [66-69]. Prolactin also increases metastatic spread $[55,56]$, and the current experiments suggest that some of this may be through induction of miR-106b, although this was not directly addressed. Rather, we showed that prolactin induced miR106b, and miR-106b in turn increased expression of fibronectin and vimentin, while anti-miR-106b decreased expression of fibronectin, vimentin, twist 2 and snail2. As p21 has been demonstrated to be an important inhibitor of the epithelialto-mesenchymal transition $[70,71]$, our data are consistent with the literature.

There are other reported targets for miR-106b, such as PTEN, SMAD7 and REST [72-75] and downregulation of these targets by miR-106b also contributes to tumor progression. For instance, a decreased PTEN level would also cause reduced p21, and decreased SMAD-7 would lead to increased epithelial to mesenchymal transition $[72,75]$. Thus, there are likely multiple integrated effects.

When looking at an effect of prolactin, one might expect it to be related to the level of expression of prolactin receptors. We did see a wide range of responsiveness to prolactin in the luciferase assay and to some extent there is a correlation. For example, in the three ovarian cancer cell lines, expression of total prolactin receptor is high in TOV-112D, modest in OV-90 and low in the TOV-21G [16]. This pattern is consistent with the miRNA production by prolactin stimulation in these three cell lines. In addition, T-47D cells express more prolactin receptors than MCF-7 cells [76] and T47D cells showed a greater response than MCF7 cells. However, PC3 cells have few prolactin receptors and yet showed a substantial response to prolactin in the luciferase assay. There must therefore be other factors at play governing this particular response to prolactin. One possible factor may be the status of p53. Under most conditions, p21 expression is p53 dependent [27].
Consistent with this suggestion, the cell lines with wild type p53, MCF-7 and TOV-21G cells, have lower induction of miR-106b by prolactin, while cell lines with mutant $\mathrm{p} 53$, TOV-112D, OV-90 and T47D, or with null p53, PC3, showed greater induction of miR-106b by prolactin.

We have previously shown that prolactin activation of Stat5 causes it to form a complex with BRCA1 that prevents BRCA1 from transactivating the $\mathrm{p} 21$ promoter [14]. We therefore expected the Jak2/Stat5 signaling pathway to be involved in the production of miR-106b since both actions lead to reduced p21. However, based on the use of signaling pathway inhibitors, Jak2 is not involved. Rather, signaling from the prolactin receptor to increased expression of miR-106b is through MAPK/ERK and PI3K/Akt. Thus, multiple signaling pathways regulate p21 levels. These pathways are also activated by membrane $\mathrm{ER} \alpha$ [77]. We therefore considered the possibility that there may be crosstalk and possible synergies between estradiol and prolactin signaling in the production of miR-106b, especially since there is synergy in terms of cell proliferation [40]. However, even though both estradiol and prolactin had similar effects in the luciferase assay, blockade/degradation of ER $\alpha$ blocked both the prolactin and estradiol effects, thereby demonstrating that ER $\alpha$ is situated between prolactin signaling and the production of miR-106b. How then does prolactin elevate expression of miR-106b? Interestingly, we have also previously shown that prolactin activation of the MAPK/ERK and PI3K/ Akt pathways leads to serine-118 phosphorylation of $\mathrm{ER} \alpha$ and its activation in the absence of an ER $\alpha$ ligand [40]. Thus, even when the use of aromatase inhibitors deprives a patient of estradiol, prolactin would still be capable of reducing expression of p21 and promoting tumor progression, although prolactin expression would also usually be reduced with aromatase inhibitors [78, 79]. However, other positive influences on prolactin production such as stress [80] and the use of some anti-psychotics [81, 82] would still be operative and capable of influencing tumor promotion through this mechanism.

In the current study, we have determined that upregulation of miR-106b by prolactin likely contributes to tumor malignancy. This upregulation is mediated through the Akt and MAPK pathways and the downstream activation of ER $\alpha$. This is diagrammed in Figure 6. Thus, miR-106b or its regulated events might serve as therapeutic targets for both breast and prostate cancers.

\section{MATERIALS AND METHODS}

\section{Cell culture}

All cell lines (human breast cancer cell lines, T47D and MCF-7, the human prostate cancer cell line, PC3, and human ovarian cancer cell lines, TOV-112D, OV-90 and TOV-21G) were freshly purchased from ATCC (Manassas, USA) where they were authenticated utilizing Short 
Tandem Repeat analysis. Cells were routinely cultured in RPMI 1640 medium supplemented with $10 \%$ fetal bovine serum (FBS) and were used for experiments with passage numbers $<20$.

\section{Production of reporter construct and pMIR luciferase assay}

The 3'UTR fragment of p21 was first amplified using the primer pair in Table 2. The amplified fragment was digested with MluI /HindIII and then ligated to the pMIR reporter vector with the same restriction enzyme digestion (Applied Biosystems, Waltham, USA) using T4 DNA ligase (New England Biolabs, Ipswich, USA). Two hundred and fifty thousand cancer cells were seeded in each well of a 12-well plate and co-transfected with the luciferase-p21 3'UTR plasmid and a $\beta$-galactosidase plasmid in the absence (Dulbecco's phosphate buffered saline - DPBS) or presence of $100 \mathrm{ng} / \mathrm{mL}$ prolactin or 1nM 17 $\beta$-estradiol for 72 hours. After 72 hours, cells were washed 2 times with DPBS and then lyzed in luciferase lysis buffer (Promega, Madison, USA). Following transfer of the lysate to a 96-well plate, the luciferin substrate (Promega, Madison, USA) was added. When examining the effect of signaling inhibitors, a shorter incubation period of 24 hours was utilized since prolonged use of signaling inhibitors is toxic to cells. For these assays, 20,000 cancer cells were seeded per well in a 96-well plate and co-transfected with the construct and $\beta$-galactosidase plasmids in the presence of the inhibitors such as to incubate cells in $20 \mu \mathrm{M}$ PD98059 (EMD Biosciences, La Jolla, USA), $1 \mu \mathrm{M}$ wortmannin (EMD Biosciences, La Jolla, USA), $10 \mu \mathrm{M}$ ICI-178280 (also known as Fulvestrant) (Sigma-Aldrich, St. Louis, USA) or $10 \mu \mathrm{M}$ AG490 (EMD Biosciences, La Jolla, USA). Four hours after transfection, medium was changed to fresh medium with the same concentrations of inhibitors in the absence or presence of prolactin $(100 \mathrm{ng} / \mathrm{mL})$. Luciferase activity was measured 24 hours after initiation of transfection, but 20 hours after the addition of prolactin. Transfection efficiency was normalized to $\beta$-galactosidase expression. Control experiments using the standard in the kit demonstrated that none of the inhibitors directly affected luciferase activity.

\section{shRNA plasmid construction}

The construction of shRNA was performed as described by [29], but in the suresilencing shRNA plasmid (SABioscience, Frederick, USA). The primers used for

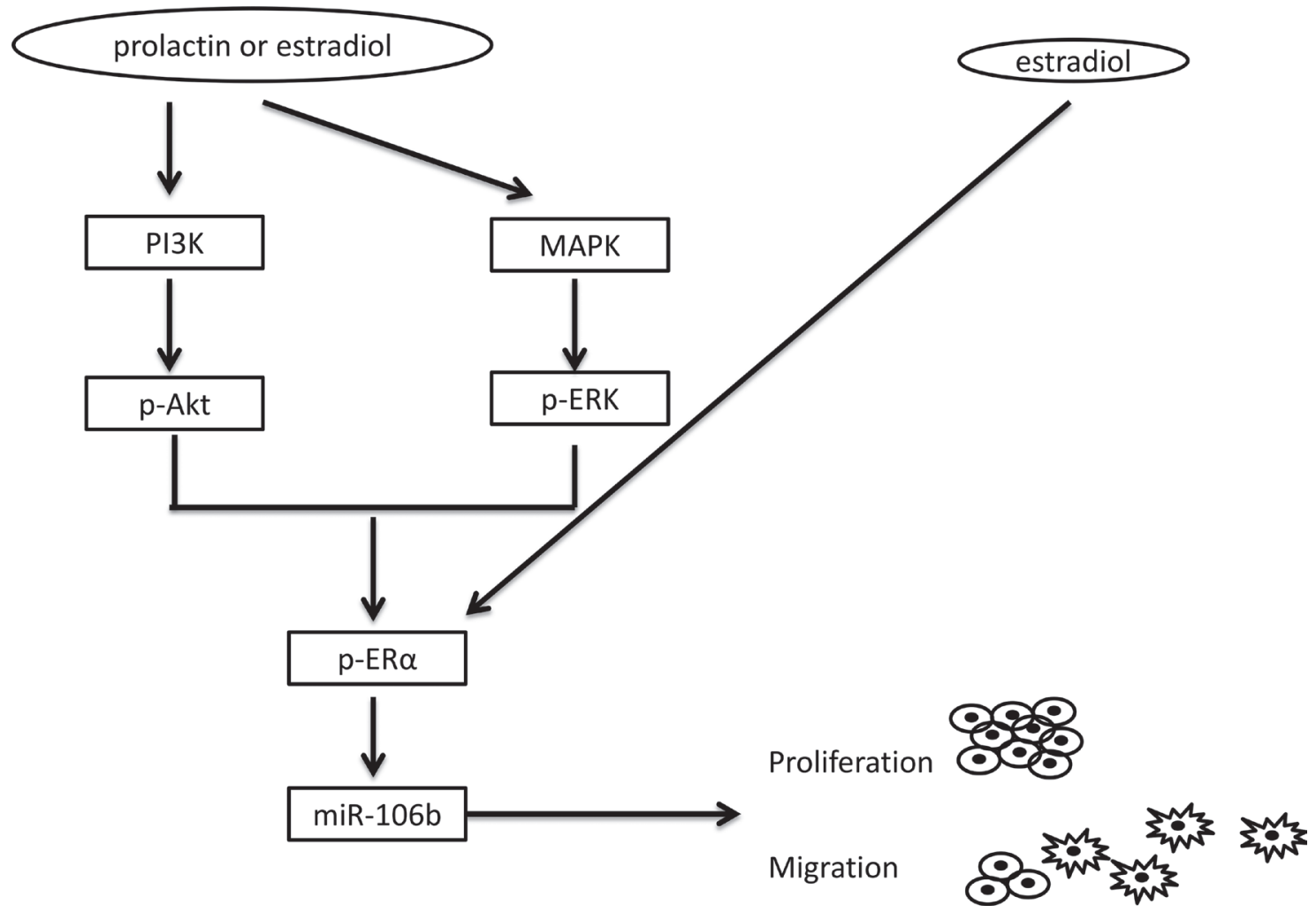

Figure 6: Model of the deduced pathway leading to tumor progression. Prolactin or estradiol activate Akt and MAPK signaling pathways via their membrane receptors. This leads to activation of ER $\alpha$. Alternatively or additionally, ER $\alpha$ may be activated directly through the classical intracellular pathway. Once ER $\alpha$ is activated by one or both hormones, expression of miR-106b is increased. Increased expression of miR-106b facilitates cell proliferation through a decrease in $\mathrm{p} 21$ and increases cell migration through upregulation of messenchymal gene expression. 
Table 2: Primers used for cloning or PCR

\begin{tabular}{|l|l|}
\hline $\begin{array}{l}\text { miR-106b } \\
\text { shRNA }\end{array}$ & $\begin{array}{l}\text { F: CTTCCTGTCATAAAGTGCTGACAGTGCAGATCTGCAGTCTGGAGTTTCA } \\
\text { R: TGACAGGAAGTAAAGTGCTGACAGTGCAGATCGAGATCTTGGGCCTCT }\end{array}$ \\
\hline $\mathbf{p 2 1}$ 3'UTR & $\begin{array}{l}\text { F: CGACGCGTCCGCCCACAGGAAG } \\
\text { R: CCAAGCTTGAGCACCTGCTGTA }\end{array}$ \\
\hline $\mathbf{p 2 1}$ & $\begin{array}{l}\text { F: CGACTGTGATGCGCTAATGG } \\
\text { R: GGCGTTTGGAGTGGTAGAAATC }\end{array}$ \\
\hline Vimentin & $\begin{array}{l}\text { F: GGACCAGCTAACCAACGACA } \\
\text { R: AAGGTCAAGACGTGCCAGAG }\end{array}$ \\
\hline Fibronectin & $\begin{array}{l}\text { F: ACAAGCATGTCTCTCTGCCA } \\
\text { R: TTTGCATCTTGGTTGGCTGC }\end{array}$ \\
\hline Twist2 & $\begin{array}{l}\text { F: CAACGCCTCCAAAAAGCCAA } \\
\text { R: ACTCACTCGCCCCAAAGATG }\end{array}$ \\
\hline GAPDH & $\begin{array}{l}\text { F: CAGAGCGACGAGATGGACAA } \\
\text { R: TGCATCCCAATTCCACTTGC }\end{array}$ \\
\hline
\end{tabular}

miR-106b shRNA construction are listed in Table 2. The outcome of increased expression of miR-106b was measured by p21 mRNA expression using real time PCR (primers in Table 2) and by the luciferase-p21 3'UTR assay described in 4.2 .

\section{Cell migration and epithelial-to-mesenchymal transition (EMT)}

One hundred thousand cancer cells, transfected with control shRNA or miR-106b shRNA were placed in a constrained area around the center of well. After 72 hours of incubation, cells were fixed with methanol for 5 min, followed by staining with $0.03 \%$ methylene blue for $10 \mathrm{~min}$. Cell movement was analyzed by comparing cell distribution between control shRNA- and shRNAmiR106-treated cells. EMT status was examined by the expression of the mesenchymal genes, snail2, fibronectin, twist2 and vimentin using real-time PCR. Gene expression was normalized to the housekeeping genes, GAPDH and $\beta$-actin. All primer information is listed in Table 2.

\section{MTS relative cell number assay}

Ten thousand cancer cells were seeded in each well of a 96-well plate and transfected with miR-106b shRNA or control plasmid. Relative cell number was assessed using a mitochondrial tetrazolium reduction assay (MTS, Promega, Madison, USA) at 72 hours.

\section{miRNA array}

Human T47D cells were seeded in $35 \mathrm{~mm}$ wells in the presence of vehicle, $100 \mathrm{ng} / \mathrm{mL}$ prolactin or S179DPRL for 72 hours. Cells were then collected for miRNA expression analysis following the instructions in the Signosis Human microRNA Array II (AP-0002) (Signosis, Santa Clara, USA).

\section{Statistical analyses}

All experiments were conducted a minimum of 3 times using a minimum of triplicates on each occasion. Statistical significance was determined by ANOVA with post tests and Bonferroni corrections for multiple comparisons, where applicable. A $P$ value $<0.05$ was considered significant.

\section{Abbreviations}

None.

\section{Authors' contributions}

Kuan-Hui Ethan Chen and Ameae Walker conceived and designed the experiments. Kuan-Hui Ethan Chen performed the experiments and analyzed the data. Karissa Bustamante performed plasmid isolations. Vi Nguyen performed part of the ICI and kinase inhibitor tests. KuanHui Ethan Chen and Ameae Walker wrote the paper.

\section{ACKNOWLEDGMENTS}

The authors thank Dr. Mary Lorenson for helpful discussions throughout the study and Connie Jury who serves as our breast cancer advocate and keeps us focused on why we are doing these experiments.

\section{CONFLICTS OF INTEREST}

All authors have declared no conflicts of interest. 


\section{FUNDING}

This work was supported by Department of Defense Breast Cancer Research Program grant, W81XWH-14-1-0425. California Breast Cancer Research Program grants, 10PB-0127 and 171B-0053, and a University of California Cancer Research Coordinating Committee Grant.

\section{REFERENCES}

1. Marano RJ, Ben-Jonathan N. Minireview: Extrapituitary prolactin: an update on the distribution, regulation, and functions. Mol Endocrinol. 2014; 28:622-33.

2. Freeman ME, Kanyicska B, Lerant A, Nagy G. Prolactin: structure, function, and regulation of secretion. Physiol Rev. 2000; 80:1523-631.

3. Tomio A, Schust DJ, Kawana K, Yasugi T, Kawana Y, Mahalingaiah S, Fujii T, Taketani Y. Prolactin can modulate CD4+ T-cell response through receptor-mediated alterations in the expression of T-bet. Immunol Cell Biol. 2008; $86: 616-21$.

4. Takizawa K, Kitani S, Takeuchi F, Yamamoto K. Enhanced expression of CD69 and CD25 antigen on human peripheral blood mononuclear cells by prolactin. Endocr J. 2005; 52:635-41.

5. Orbach H, Shoenfeld Y. Hyperprolactinemia and autoimmune diseases. Autoimmun Rev. 2007; 6:537-42.

6. Viengchareun S, Servel N, Fève B, Freemark M, Lombès M, Binart N. Prolactin receptor signaling is essential for perinatal brown adipocyte function: a role for insulin-like growth factor-2. PLoS One. 2008; 3:e1535.

7. Baptista T, Lacruz A, de Mendoza S, Mendoza Guillén JM, Silvera R, Angeles F, Mendoza MT, Hernández L. Body weight gain after administration of antipsychotic drugs: correlation with leptin, insulin and reproductive hormones. Pharmacopsychiatry. 2000; 33:81-8.

8. Huang C, Snider F, Cross JC. Prolactin receptor is required for normal glucose homeostasis and modulation of beta-cell mass during pregnancy. Endocrinology. 2009; 150:1618-26.

9. Friedrichsen BN, Galsgaard ED, Nielsen JH, Møldrup A. Growth hormone- and prolactin-induced proliferation of insulinoma cells, INS-1, depends on activation of STAT5 (signal transducer and activator of transcription 5). Mol Endocrinol. 2001; 15:136-48.

10. Seriwatanachai D, Thongchote K, Charoenphandhu N, Pandaranandaka J, Tudpor K, Teerapornpuntakit J, Suthiphongchai T, Krishnamra N. Prolactin directly enhances bone turnover by raising osteoblast-expressed receptor activator of nuclear factor kappaB ligand/ osteoprotegerin ratio. Bone. 2008; 42:535-46.

11. Meaney AM, Smith S, Howes OD, O'Brien M, Murray RM, O'Keane V. Effects of long-term prolactin-raising antipsychotic medication on bone mineral density in patients with schizophrenia. Br J Psychiatry. 2004; 184:503-8.
12. Barcus CE, Keely PJ, Eliceiri KW, Schuler LA. Prolactin signaling through focal adhesion complexes is amplified by stiff extracellular matrices in breast cancer cells. Oncotarget. 2016; 7:48093-106. doi: 10.18632/oncotarget.10137.

13. Vonderhaar BK. Prolactin involvement in breast cancer. Endocr Relat Cancer. 1999; 6:389-404.

14. Chen KH, Walker AM. Prolactin inhibits a major tumorsuppressive function of wild type BRCA1. Cancer Lett. 2016; 375:293-302.

15. Xu X, Kreye E, Kuo CB, Walker AM. A molecular mimic of phosphorylated prolactin markedly reduced tumor incidence and size when DU145 human prostate cancer cells were grown in nude mice. Cancer Res. 2001; 61:6098-104.

16. Tan D, Chen KE, Khoo T, Walker AM. Prolactin increases survival and migration of ovarian cancer cells: importance of prolactin receptor type and therapeutic potential of S179D and G129R receptor antagonists. Cancer Lett. 2011; 310:101-8.

17. Kong X, Wu W, Yuan Y, Pandey V, Wu Z, Lu X, Zhang W, Chen Y, Wu M, Zhang M, Li G, Tan S, Qian P, et al. Human growth hormone and human prolactin function as autocrine/ paracrine promoters of progression of hepatocellular carcinoma. Oncotarget. 2016; 7:29465-79. doi: 10.18632/ oncotarget.8781.

18. Alkharusi A, Yu S, Landázuri N, Zadjali F, Davodi B, Nyström T, Gräslund T, Rahbar A, Norstedt G. Stimulation of prolactin receptor induces STAT-5 phosphorylation and cellular invasion in glioblastoma multiforme. Oncotarget. 2016; 7:79572-83. doi: 10.18632/oncotarget.12840.

19. Krown KA, Wang YF, Ho TW, Kelly PA, Walker AM. Prolactin isoform 2 as an autocrine growth factor for GH3 cells. Endocrinology. 1992; 131:595-602.

20. Xie W, Liu C, Wu D, Li Z, Li C, Zhang Y. Phosphorylation of kinase insert domain receptor by cyclin-dependent kinase 5 at serine 229 is associated with invasive behavior and poor prognosis in prolactin pituitary adenomas. Oncotarget. 2016; 7:50883-94. doi: 10.18632/oncotarget.10550.

21. Cariou S, Donovan JC, Flanagan WM, Milic A, Bhattacharya N, Slingerland JM. Down-regulation of p21WAF1/CIP1 or p27Kip1 abrogates antiestrogenmediated cell cycle arrest in human breast cancer cells. Proc Natl Acad Sci USA. 2000; 97:9042-6.

22. Liao XH, Lu DL, Wang N, Liu LY, Wang Y, Li YQ, Yan TB, Sun $\mathrm{XG}, \mathrm{Hu} \mathrm{P}$, Zhang TC. Estrogen receptor $\alpha$ mediates proliferation of breast cancer MCF-7 cells via a p21/PCNA/ E2F1-dependent pathway. FEBS J. 2014; 281:927-42.

23. Abukhdeir AM, Vitolo MI, Argani P, De Marzo AM, Karakas B, Konishi H, Gustin JP, Lauring J, Garay JP, Pendleton C, Konishi Y, Blair BG, Brenner K, et al. Tamoxifen-stimulated growth of breast cancer due to $\mathrm{p} 21$ loss. Proc Natl Acad Sci U S A. 2008; 105:288-93.

24. Riggins RB, Schrecengost RS, Guerrero MS, Bouton AH. Pathways to tamoxifen resistance. Cancer Lett. 2007; 256:1-24.

25. Musgrove EA, Sutherland RL. Biological determinants of endocrine resistance in breast cancer. Nat Rev Cancer. 2009; 9:631-43. 
26. Abukhdeir AM, Park BH. P21 and p27: roles in carcinogenesis and drug resistance. Expert Rev Mol Med. 2008; 10:e19.

27. el-Deiry WS, Harper JW, O'Connor PM, Velculescu VE, Canman CE, Jackman J, Pietenpol JA, Burrell M, Hill DE, Wang Y. WAF1/CIP1 is induced in p53-mediated G1 arrest and apoptosis. Cancer Res. 1994; 54:1169-74.

28. Somasundaram K, Zhang H, Zeng YX, Houvras Y, Peng Y, Wu GS, Licht JD, Weber BL, El-Deiry WS. Arrest of the cell cycle by the tumour-suppressor BRCA1 requires the CDK-inhibitor p21WAF1/CiP1. Nature. 1997; 389:187-90.

29. Datto MB, Li Y, Panus JF, Howe DJ, Xiong Y, Wang XF. Transforming growth factor beta induces the cyclindependent kinase inhibitor p21 through a p53-independent mechanism. Proc Natl Acad Sci U S A. 1995; 92:5545-9.

30. Liu M, Iavarone A, Freedman LP. Transcriptional activation of the human p21(WAF1/CIP1) gene by retinoic acid receptor. Correlation with retinoid induction of U937 cell differentiation. J Biol Chem. 1996; 271:31723-8.

31. Liu M, Lee MH, Cohen M, Bommakanti M, Freedman LP. Transcriptional activation of the $\mathrm{Cdk}$ inhibitor $\mathrm{p} 21$ by vitamin D3 leads to the induced differentiation of the myelomonocytic cell line U937. Genes Dev. 1996; 10:142-53.

32. Koster R, di Pietro A, Timmer-Bosscha H, Gibcus JH, van den Berg A, Suurmeijer AJ, Bischoff R, Gietema JA, de Jong S. Cytoplasmic p21 expression levels determine cisplatin resistance in human testicular cancer. J Clin Invest. 2010; 120:3594-605.

33. Zhang Y, Wang Z, Magnuson NS. Pim-1 kinase-dependent phosphorylation of $\mathrm{p} 21 \mathrm{Cip} 1 / \mathrm{WAF} 1$ regulates its stability and cellular localization in H1299 cells. Mol Cancer Res. 2007; 5:909-22.

34. Suzuki A, Kawano H, Hayashida M, Hayasaki Y, Tsutomi Y, Akahane K. Procaspase 3/p21 complex formation to resist fas-mediated cell death is initiated as a result of the phosphorylation of p21 by protein kinase A. Cell Death Differ. 2000; 7:721-8.

35. Makker A, Goel MM. Tumor progression, metastasis, and modulators of epithelial-mesenchymal transition in endometrioid endometrial carcinoma: an update. Endocr Relat Cancer. 2016; 23:R85-R111.

36. Simões BM, Alferez DG, Howell SJ, Clarke RB. The role of steroid hormones in breast cancer stem cells. Endocr Relat Cancer. 2015; 22:T177-86.

37. Reznikov A. Hormonal impact on tumor growth and progression. Exp Oncol. 2015; 37:162-72.

38. Barrett-Connor E. Postmenopausal estrogen and the risk of breast cancer. Ann Epidemiol. 1994; 4:177-80.

39. Oladimeji P, Skerl R, Rusch C, Diakonova M. Synergistic Activation of ER $\alpha$ by Estrogen and Prolactin in Breast Cancer Cells Requires Tyrosyl Phosphorylation of PAK1. Cancer Res. 2016; 76:2600-11.

40. Chen Y, Huang K, Chen KE, Walker AM. Prolactin and estradiol utilize distinct mechanisms to increase serine-118 phosphorylation and decrease levels of estrogen receptor alpha in T47D breast cancer cells. Breast Cancer Res Treat. 2010; 120:369-77.

41. Rasmussen LM, Frederiksen KS, Din N, Galsgaard E, Christensen L, Berchtold MW, Panina S. Prolactin and oestrogen synergistically regulate gene expression and proliferation of breast cancer cells. Endocr Relat Cancer. 2010; 17:809-22.

42. Gutzman JH, Nikolai SE, Rugowski DE, Watters JJ, Schuler LA. Prolactin and estrogen enhance the activity of activating protein 1 in breast cancer cells: role of extracellularly regulated kinase 1/2-mediated signals to c-fos. Mol Endocrinol. 2005; 19:1765-78.

43. Wu W, Ginsburg E, Vonderhaar BK, Walker AM. S179D prolactin increases vitamin $\mathrm{D}$ receptor and p21 through upregulation of short $1 \mathrm{~b}$ prolactin receptor in human prostate cancer cells. Cancer Res. 2005; 65:7509-15.

44. Tan D, Johnson DA, Wu W, Zeng L, Chen YH, Chen WY, Vonderhaar BK, Walker AM. Unmodified prolactin (PRL) and S179D PRL-initiated bioluminescence resonance energy transfer between homo- and hetero-pairs of long and short human PRL receptors in living human cells. Mol Endocrinol. 2005; 19:1291-303.

45. Kuo CB, Wu W, Xu X, Yang L, Chen C, Coss D, Birdsall B, Nasseri D, Walker AM. Pseudophosphorylated prolactin (S179D PRL) inhibits growth and promotes beta-casein gene expression in the rat mammary gland. Cell Tissue Res. 2002; 309:429-37.

46. Wu W, Chen YH, Ueda E, Tan D, Bartolini P, Walker AM. Different forms of prolactin have opposing effects on the expression of cell cycle regulatory proteins in differentiated mammary epithelial cells. Oncol Res. 2006; 16:75-84.

47. Ivanovska I, Ball AS, Diaz RL, Magnus JF, Kibukawa M, Schelter JM, Kobayashi SV, Lim L, Burchard J, Jackson AL, Linsley PS, Cleary MA. MicroRNAs in the miR-106b family regulate $\mathrm{p} 21 / \mathrm{CDKN} 1 \mathrm{~A}$ and promote cell cycle progression. Mol Cell Biol. 2008; 28:2167-74.

48. Wong N, Wang X. miRDB: an online resource for microRNA target prediction and functional annotations. Nucleic Acids Res. 2015; 43:D146-52.

49. Wang X. Improving microRNA target prediction by modeling with unambiguously identified microRNA-target pairs from CLIP-ligation studies. Bioinformatics. 2016; 32:1316-22.

50. Li F, Liu B, Gao Y, Liu Y, Xu Y, Tong W, Zhang A. Upregulation of microRNA-107 induces proliferation in human gastric cancer cells by targeting the transcription factor FOXO1. FEBS Lett. 2014; 588:538-44.

51. Wu Z, He B, He J, Mao X. Upregulation of miR-153 promotes cell proliferation via downregulation of the PTEN tumor suppressor gene in human prostate cancer. Prostate. 2013; 73:596-604.

52. Jingjing Z, Xiaoxiao T, Yu Z, Yanli B, Ke P. MiR-142-3p is a tumor promoter by directly targeting $\mathrm{FOXO} 4$ to promote 
gastric cancer cell growth and suppress cell apoptosis in gastric cancer. Int J Clin Exp Pathol. 2016; 9:12079-12087.

53. Vanhaesebroeck B, Leevers SJ, Ahmadi K, Timms J, Katso R, Driscoll PC, Woscholski R, Parker PJ, Waterfield MD. Synthesis and function of 3-phosphorylated inositol lipids. Annu Rev Biochem. 2001; 70:535-602.

54. Ruffion A, Al-Sakkaf KA, Brown BL, Eaton CL, Hamdy FC, Dobson PR. The survival effect of prolactin on PC3 prostate cancer cells. Eur Urol. 2003; 43:301-8.

55. Yonezawa T, Chen KH, Ghosh MK, Rivera L, Dill R, Ma L, Villa PA, Kawaminami M, Walker AM. Anti-metastatic outcome of isoform-specific prolactin receptor targeting in breast cancer. Cancer Lett. 2015; 366:84-92.

56. Sutherland A, Forsyth A, Cong Y, Grant L, Juan TH, Lee JK, Klimowicz A, Petrillo SK, Hu J, Chan A, Boutillon F, Goffin V, Egan C, et al. The Role of Prolactin in Bone Metastasis and Breast Cancer Cell-Mediated Osteoclast Differentiation. J Natl Cancer Inst. 2016; 108.

57. LaPensee EW, Schwemberger SJ, LaPensee CR, Bahassi el M, Afton SE, Ben-Jonathan N. Prolactin confers resistance against cisplatin in breast cancer cells by activating glutathione-Stransferase. Carcinogenesis. 2009; 30:1298-304.

58. LaPensee EW, Ben-Jonathan N. Novel roles of prolactin and estrogens in breast cancer: resistance to chemotherapy. Endocr Relat Cancer. 2010; 17:R91-107.

59. Schroeder MD, Brockman JL, Walker AM, Schuler LA. Inhibition of prolactin (PRL)-induced proliferative signals in breast cancer cells by a molecular mimic of phosphorylated PRL, S179D-PRL. Endocrinology. 2003; 144:5300-7.

60. Asher JM, O'Leary KA, Rugowski DE, Arendt LM, Schuler LA. Prolactin promotes mammary pathogenesis independently from cyclin D1. Am J Pathol. 2012; 181:294-302.

61. Cheng J, Deng R, Zhang P, Wu C, Wu K, Shi L, Liu X, Bai J, Deng M, Shuai X, Gao J, Wang G, Tao K. miR219-5p plays a tumor suppressive role in colon cancer by targeting oncogene Sall4. Oncol Rep. 2015; 34:1923-32.

62. Lahdaoui F, Delpu Y, Vincent A, Renaud F, Messager M, Duchêne B, Leteurtre E, Mariette C, Torrisani J, Jonckheere N, Van Seuningen I. miR-219-1-3p is a negative regulator of the mucin MUC4 expression and is a tumor suppressor in pancreatic cancer. Oncogene. 2015; 34:780-8.

63. Shi F, Chen X, Fu A, Hansen J, Stevens R, Tjonneland A, Vogel UB, Zheng T, Zhu, Y. Aberrant DNA methylation of miR-219 promoter in long-term night shiftworkers. Environ Mol Mutagen. 2013; 54:406-13.

64. Gong C, Qu S, Liu B, Pan S, Jiao Y, Nie Y, Su F, Liu Q, Song E. MiR-106b expression determines the proliferation paradox of TGF- $\beta$ in breast cancer cells. Oncogene. 2015; 34:84-93.

65. Yau WL, Lam CS, Ng L, Chow AK, Chan ST, Chan JY, Wo JY, Ng KT, Man K, Poon RT, Pang RW. Overexpression of miR-106b promotes cell migration and metastasis in hepatocellular carcinoma by activating epithelial-mesenchymal transition process. PLoS One. 2013; 8:e57882.

66. Hudson RS, Yi M, Esposito D, Glynn SA, Starks AM, Yang Y, Schetter AJ, Watkins SK, Hurwitz AA, Dorsey TH, Stephens RM, Croce CM, Ambs S. MicroRNA-106b-25 cluster expression is associated with early disease recurrence and targets caspase- 7 and focal adhesion in human prostate cancer. Oncogene. 2013; 32:4139-47.

67. Li N, Liu Y, Miao Y, Zhao L, Zhou H, Jia L. MicroRNA106b targets FUT6 to promote cell migration, invasion, and proliferation in human breast cancer. IUBMB Life. 2016; 68:764-75.

68. Zhou Y, Hu Y, Yang M, Jat P, Li K, Lombardo Y, Xiong D, Coombes RC, Raguz S, Yagüe E. The miR-106b 25 cluster promotes bypass of doxorubicin-induced senescence and increase in motility and invasion by targeting the E-cadherin transcriptional activator EP300. Cell Death Differ. 2014; 21:462-74

69. Li SD, Zhang JR, Wang YQ, Wan XP. The role of microRNAs in ovarian cancer initiation and progression. J Cell Mol Med. 2010; 14:2240-9.

70. Liu M, Casimiro MC, Wang C, Shirley LA, Jiao X, Katiyar S, Ju X, Li Z, Yu Z, Zhou J, Johnson M, Fortina P, Hyslop T, et al. p21CIP1 attenuates Ras- and c-Myc-dependent breast tumor epithelial mesenchymal transition and cancer stem cell-like gene expression in vivo. Proc Natl Acad Sci U S A. 2009; 106:19035-9.

71. Zhang Y, Yan W, Jung YS, Chen X. PUMA Cooperates with p21 to Regulate Mammary Epithelial Morphogenesis and Epithelial-To-Mesenchymal Transition. PLoS One. 2013; 8:e66464.

72. Zhou K, Zhang T, Fan Y, Serick, Du G, Wu P, Geng D. MicroRNA-106b promotes pituitary tumor cell proliferation and invasion through PI3K/AKT signaling pathway by targeting PTEN. Tumour Biol. 2016; 37:13469-77.

73. Liang H, Studach L, Hullinger RL, Xie J, Andrisani OM. Down-regulation of RE-1 silencing transcription factor (REST) in advanced prostate cancer by hypoxia-induced miR-106b 25. Exp Cell Res. 2014; 320:188-99.

74. Dhar S, Kumar A, Rimando AM, Zhang X, Levenson AS. Resveratrol and pterostilbene epigenetically restore PTEN expression by targeting oncomiRs of the miR-17 family in prostate cancer. Oncotarget. 2015; 6:27214-26. doi: 10.18632/oncotarget.4877.

75. Smith AL, Iwanaga R, Drasin DJ, Micalizzi DS, Vartuli RL, Tan AC, Ford HL. The miR-106b-25 cluster targets Smad7, activates TGF- $\beta$ signaling, and induces EMT and tumor initiating cell characteristics downstream of Six 1 in human breast cancer. Oncogene. 2012; 31:5162-71.

76. Galsgaard ED, Rasmussen BB, Folkesson CG, Rasmussen LM, Berchtold MW, Christensen L, Panina S. Re-evaluation of the prolactin receptor expression in human breast cancer. J Endocrinol. 2009; 201:115-28.

77. Titolo D, Mayer CM, Dhillon SS, Cai F, Belsham DD. Estrogen facilitates both phosphatidylinositol 3-kinase/ 
Akt and ERK1/2 mitogen-activated protein kinase membrane signaling required for long-term neuropeptide $\mathrm{Y}$ transcriptional regulation in clonal, immortalized neurons. J Neurosci. 2008; 28:6473-82.

78. Ben-Jonathan N, Chen S, Dunckley JA, LaPensee C, Kansra S. Estrogen receptor-alpha mediates the epidermal growth factor-stimulated prolactin expression and release in lactotrophs. Endocrinology. 2009; 150:795-802.

79. Duan R, Ginsburg E, Vonderhaar BK. Estrogen stimulates transcription from the human prolactin distal promoter through AP1 and estrogen responsive elements in T47D human breast cancer cells. Mol Cell Endocrinol. 2008; 281:9-18.
80. Torner L, Neumann ID. The brain prolactin system: involvement in stress response adaptations in lactation. Stress. 2002; 5:249-57.

81. Albayrak Y, Beyazyüz M, Beyazyüz E, Kuloğlu M. Increased serum prolactin levels in drug-naive first-episode male patients with schizophrenia. Nord J Psychiatry. 2014; 68:341-6.

82. Renn JH, Yang NP, Chou P. Effects of plasma magnesium and prolactin on quantitative ultrasound measurements of heel bone among schizophrenic patients. BMC Musculoskelet Disord. 2010; 11:35. 